\title{
An Economic Analysis Measuring the Interdependance of Janan and the U.S.
}

\author{
Pete Mavrokordatos, Stan Stascinsky \\ Alexander College, Cyprus \\ Tarrant County College, USA \\ Pete Mavrokordatos
}

\begin{abstract}
The title of the paper is a very good indication about what the paper is all about. The authors' goal first is to study the historical development of Japan, the second biggest economy of the world. In our attempt to do that, we are going to present a lot of historical data, to show the development of Japan during the centuries of its history. In a different section, we are going to present Japan and the United States in numbers, to get a better picture how these two economic super powers compare. The figures will be presented in tables as well as graphs for an easier understanding. In the last section, which is the statistical analysis section, we are going to run several regressions in order to measure the economic impact that each one of these countries has on the other.
\end{abstract}

Keywords: US - Japan Economic Analysis

\section{Introduction}

Japan has a history that goes back thousands of years. Just like any other country's history, it had to start from somewhere. No one knows exactly when and where the Japanese people came, but for sure just like in any other country, they moved there from somewhere else. Even though it is not exactly known, where these people came from, this mixture of people arrived at different times and from different places. Eventually they were homogenized, and were able to distinguish themselves from the Chinese, the Koreans and the Mongols in terms of language, physical traits, religion, political and social structure.

One question that arises at this point then, is when did the Japanese state actually formed. There are no solid answers to this, but there are some strong assumptions. With respect to this question, two of the earliest Japanese histories, the Kojiki and the Nihon shoki, take us back to around 712 to 720 , and others take us back to the 660 B.C. On the other hand more recent historians claim that political unity in Japan took place at the end of the $3^{\text {rd }}$ century A.D. or the beginning of the $4^{\text {th }}$ century A.D. which was the time of the appearance of the Kofun tumuli. This theory seems to be the one that draws most of the support. 
As mentioned earlier the Japanese history goes back thousands of years, and cannot be discussed in just a few pages. It is worthwhile though to mention a few of the most important periods.

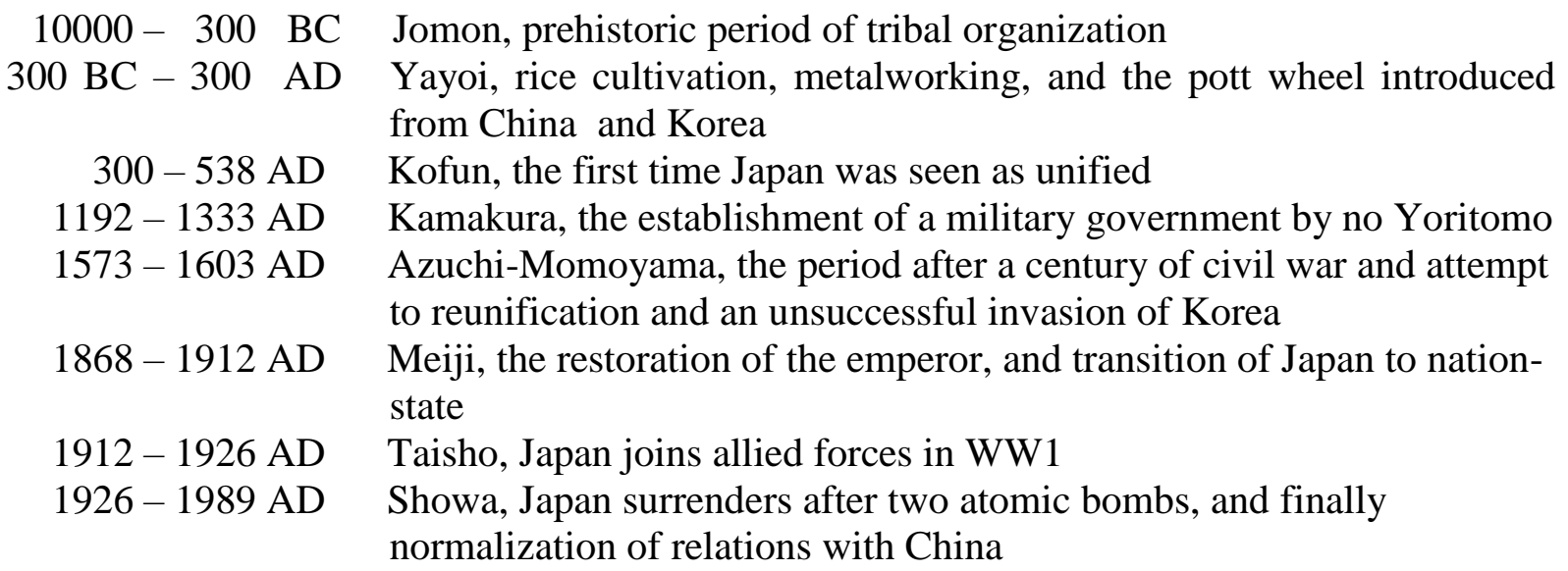

In conclusion, this section, very briefly presented some of the most important periods of the Japanese history.

\section{CURRENT LITERATURE}

In the Current Literature section, the authors will present to the reader the most recent information about the Japanese economy, as well as the U.S. economy and this is designed to prepare the reader for the next section. Since the Appendix presents an in depth comparison between Japan and the United States, using several regression models, some comparison in some areas will be done in this section as well. Also in this section, we'll discuss the reasons for the tremendous growth that Japan had for years, and then present the current situation.

The Japanese economy is known as a two tiered economy. The reason for that is that it consists of two tiers. The first consists of the large multinational companies, and the other one consists of a large number of small mostly family owned enterprises. What is interesting about this second tier is that in $2000,99.4 \%$ of manufacturing was done in this tier, by companies of 300 or less employees.

Another important characteristic of the Japanese economy is that manufacturing is its most important component, and today it stands around 20\% plus of its GDP. Besides manufacturing though, another important component of this economy is investment. During the late 1990s and the early years of the $21^{\text {st }}$ century, gross fixed investment, both in the private sector and the public sector accounted for $24-27 \%$ of the GDP, and this is higher than that of Germany and the U.S.

Finally, it seems that the Japanese economy remains strong due to the low openness to foreign trade. In 2015 total foreign trade in Japan was 35.6\% of its GDP, whereas in Germany that figures was $54 \%$. In the U.S. this figure during 2015 was around $28 \%$. This low openness to 
foreign trade is mostly due to restrictions on merchandise imports, in order to help the less efficient sectors, even though the U.S. puts pressure on the Japanese to eliminate some of the restrictions.

At this point, the authors believe that it is worthwhile to do a brief comparison between Japan and the U.S. since they are the biggest and most competitive economies of the world. There is a widespread belief that even though the United States was at one time the greatest economy in the world, starting in the mid 1970s, the Japanese have surpassed the Americans. A lot of people believe that the things that contributed to this were such practices as permanent employment and the seniority system. On the other hand, there is data available that contradicts these beliefs. It is well known that Japan and the U.S. are responsible for $30 \%$ to $40 \%$ of world output, but the Japanese output is only $42 \%$ of that of the U.S. Also the Japanese per capita income is only $83 \%$ of the U.S. per capita income.

Another thing that questions the belief that the Japanese have surpassed the Americans, has to do with government regulation. In order for any system to flourish, it must have maximum flexibility in the private sector. In Japan though this is not the case. Here we find a very high level of regulation, and this is why the Japanese pay at least 30\% more than the Americans for goods and services. The conclusion that is derived here is that if Japan wants to remain competitive internationally, most of these regulations must be eliminated.

Even though as discussed above, the Japanese economy is not stronger and bigger than that of the U.S. we all agree that it is a close second and the following are some of the most important reasons that contributed to that.

1. State - assisted capitalism: the government plays a big role in determining what to produce Etc

2. The occupation: as a result of the occupation of Japan, the American policies encouraged higher savings rates and lower inflation

3. The Korean war: American purchases from Japan during the war, turned into an economic boost

4. The world free trade boom: free trade encouraged Japanese exports

5. A surplus of well educated workers: the Japanese have a very well educated labor force

6. A stable political situation: Japan has a very stable political system

7.

Along with these reasons, there were some others as well of less importance. Nevertheless they contributed to the so called Japanese economic miracle.

A lot of information has been presented and discussed in this section that shows the current situation in Japan. The following though will summarize it in the most accurate way:

1. Some major concerns in Japan are about employment, pension plans and government deficits. All of these of course limit the economic turnaround.

2. The social system that supposedly was promoting equality, has generated inefficient 
resource allocation. Good examples of this are excessive regulation and overprotection.

3. The Japanese management style compared to international standards has become obsolete, and their financial system does not work anymore.

In conclusion, the Japanese have made some changes and adjustments, but as can be seen in this section, they still face serious problems. The last section, Conclusion/Recommendations, will put together some suggestions how things can be turned around.

\section{U. S. - JAPAN IN FIGURES}

In this section, as mentioned in the previous section, the authors are going to present a lot of economic data for Japan and the United States. On the one hand we like to show the economic conditions of Japan, and on the other we like to compare the Japanese economy to that of the United States, as two of the most developed and biggest economies of the world. The data that will be presented includes the Gross Domestic Product, the Growth Rates, the total trade of each one of the two countries, Unemployment Rates and the Inflation Rates. Some of this data will be shown in graphs as well for better comparison. The Gross Domestic Product figures, show that both economies are growing economies, and although the Japanese economy is less than 50\% of that of the U.S., even though there were years, that Japan was growing faster, but there were also times, that Japan had a negative growth, but so did the U.S. This is shown on Figure 1.

The next data presented, in Table 1 below, includes the unemployment rates and the inflation rates. Both the unemployment rates and the inflation rates of Japan, for most of the years are lower than those of the U.S., and at this point further research and study should be done to determine the impact that the U.S. has on this, specifically the fact that the U.S. imports so much from Japan. Both of these indicators are shown on Figure 2 and 3.

Finally, Figures 4 and 5 show the data found in Table 2. Figure 4 shows a comparison of exports $(\mathrm{X})$, imports $(\mathrm{M})$ and net exports $(\mathrm{X}-\mathrm{M})$ for both countries.

Figure 5 shows the population size for each country, and even though the U.S. population is three times the population of Japan, it is obvious from the graph that both countries have a growing population.

TABLE 1

U.S. - JAPAN DATA 1971 - 2015

\begin{tabular}{|c|c|c|c|c|c|c|c|c|}
\hline YEAR & $\begin{array}{l}\text { JAP. } \\
\text { GDP }\end{array}$ & $\begin{array}{l}\text { U.S. } \\
\text { GDP }\end{array}$ & $\begin{array}{l}\text { JAP. } \\
\text { GDP }\end{array}$ & $\begin{array}{l}\text { U.S. } \\
\text { GDP }\end{array}$ & $\begin{array}{l}\text { JAP. } \\
\text { INFL. }\end{array}$ & $\begin{array}{l}\text { U.S. } \\
\text { INFL. }\end{array}$ & $\begin{array}{l}\text { JAP. } \\
\text { UN. }\end{array}$ & $\begin{array}{l}\text { U.S. } \\
\text { UN. }\end{array}$ \\
\hline & $\begin{array}{l}2010 \\
\text { US\$ }\end{array}$ & $\begin{array}{l}2010 \\
\text { US\$ }\end{array}$ & $\begin{array}{l}\text { GR. R. } \\
\%\end{array}$ & $\begin{array}{l}\text { GR. R. } \\
\%\end{array}$ & & & & \\
\hline 1971 & 2.01 & 4.94 & 4.69 & 3.29 & 6.35 & 4.25 & 1.23 & 5.94 \\
\hline 1972 & 2.18 & 5.2 & 8.41 & 5.26 & 4.84 & 3.3 & 1.4 & 5.61 \\
\hline
\end{tabular}




\begin{tabular}{|c|c|c|c|c|c|c|c|c|}
\hline 1973 & 2.36 & 5.49 & 8.03 & 5.64 & 11.62 & 6.22 & 1.28 & 4.88 \\
\hline 1974 & 2.33 & 5.46 & -1.22 & -0.52 & 23.17 & 11.03 & 1.37 & 5.61 \\
\hline 1975 & 2.4 & 5.45 & 3.09 & -0.19 & 11.77 & 9.13 & 1.88 & 8.46 \\
\hline 1976 & 2.5 & 5.74 & 3.97 & 5.38 & 9.39 & 5.73 & 2.01 & 7.7 \\
\hline 1977 & 2.61 & 6.01 & 4.39 & 4.61 & 8.13 & 6.48 & 2.02 & 7.06 \\
\hline 1978 & 2.74 & 6.34 & 5.27 & 5.56 & 4.21 & 7.64 & 2.24 & 6.07 \\
\hline 1979 & 2.9 & 6.55 & 5.48 & 3.17 & 3.69 & 11.26 & 2.09 & 5.85 \\
\hline 1980 & 2.98 & 6.53 & 2.81 & -0.24 & 7.81 & 13.5 & 2.02 & 7.14 \\
\hline 1981 & 3.1 & 6.7 & 4.17 & 2.59 & 4.91 & 10.31 & 2.21 & 7.61 \\
\hline 1982 & 3.21 & 6.57 & 3.37 & -1.91 & 2.71 & 6.16 & 2.36 & 9.69 \\
\hline 1983 & 3.3 & 6.87 & 3.06 & 4.63 & 1.87 & 3.21 & 2.65 & 9.61 \\
\hline 1984 & 3.45 & 7.37 & 4.46 & 7.25 & 2.29 & 4.31 & 2.72 & 7.52 \\
\hline 1985 & 3.67 & 7.69 & 6.32 & 4.23 & 2.03 & 3.56 & 2.62 & 7.2 \\
\hline 1986 & 3.77 & 7.96 & 2.83 & 3.51 & 0.6 & 1.85 & 2.77 & 6.99 \\
\hline 1987 & 3.93 & 8.23 & 4.1 & 3.46 & 0.14 & 3.74 & 2.84 & 6.19 \\
\hline 1988 & 4.21 & 8.58 & 7.14 & 4.2 & 0.66 & 4 & 2.51 & 5.51 \\
\hline 1989 & 4.44 & 8.89 & 5.37 & 3.68 & 2.27 & 4.82 & 2.26 & 5.27 \\
\hline 1990 & 4.68 & 9.06 & 5.57 & 1.91 & 3.03 & 5.39 & 2.1 & 5.6 \\
\hline 1991 & 4.84 & 9.06 & 3.32 & -0.07 & 3.29 & 4.23 & 2.09 & 6.83 \\
\hline 1992 & 4.88 & 9.38 & 0.82 & 3.55 & 1.7 & 3.02 & 2.16 & 7.5 \\
\hline 1993 & 4.89 & 9.64 & 0.17 & 2.74 & 1.26 & 2.95 & 2.51 & 6.92 \\
\hline 1994 & 4.93 & 10 & 0.86 & 4.03 & 0.68 & 2.6 & 2.89 & 6.1 \\
\hline 1995 & 5.06 & 10.3 & 2.74 & 2.72 & -0.12 & 2.8 & 3.15 & 5.6 \\
\hline 1996 & 5.22 & 10.7 & 3.09 & 3.79 & 0.13 & 2.93 & 3.35 & 5.4 \\
\hline 1997 & 5.28 & 11.2 & 1.07 & 4.48 & 1.76 & 2.33 & 3.39 & 4.94 \\
\hline 1998 & 5.22 & 11.7 & -1.12 & 4.45 & 0.66 & 1.55 & 4.11 & 4.51 \\
\hline 1999 & 5.2 & 12.2 & -0.25 & 4.68 & -0.33 & 2.18 & 4.68 & 4.22 \\
\hline 2000 & 5.35 & 12.7 & 2.77 & 4.09 & -0.65 & 3.37 & 4.73 & 3.99 \\
\hline 2001 & 5.37 & 12.8 & 0.4 & 0.97 & -0.74 & 2.82 & 5.04 & 4.33 \\
\hline 2002 & 5.38 & 13.1 & 0.11 & 1.78 & -0.92 & 1.58 & 5.37 & 5.78 \\
\hline 2003 & 4.46 & 13.4 & 1.52 & 2.8 & -0.25 & 2.27 & 5.25 & 5.99 \\
\hline 2004 & 5.58 & 13.9 & 2.2 & 3.78 & -0.01 & 2.67 & 4.71 & 5.53 \\
\hline 2005 & 5.67 & 14.4 & 1.66 & 3.34 & -0.28 & 3.39 & 4.42 & 5.08 \\
\hline 2006 & 5.75 & 14.8 & 1.42 & 2.66 & 0.24 & 3.22 & 4.13 & 4.62 \\
\hline 2007 & 5.85 & 15.1 & 1.65 & 1.77 & 0.06 & 2.85 & 3.85 & 4.62 \\
\hline 2008 & 5.78 & 15 & -1.09 & -0.29 & 1.38 & 3.83 & 3.98 & 5.78 \\
\hline 2009 & 5.47 & 14.6 & -5.41 & -2.77 & -1.35 & -0.35 & 5.08 & 9.25 \\
\hline 2010 & 5.7 & 15 & 4.19 & 2.53 & -0.72 & 1.64 & 5.07 & 9.63 \\
\hline 2011 & 5.69 & 1502 & -0.11 & 1.6 & -0.26 & 3.15 & 4.55 & 8.95 \\
\hline
\end{tabular}




\begin{tabular}{|l|r|r|r|r|r|r|r|r|}
\hline 2012 & 5.78 & 15.5 & 1.49 & 2.22 & -0.05 & 2.06 & 4.35 & 8.07 \\
\hline 2013 & 5.89 & 15.8 & 2 & 1.68 & 0.34 & 1.46 & 4.03 & 7.38 \\
\hline 2014 & 5.91 & 16.2 & 0.33 & 2.37 & 2.76 & 1.62 & 3.58 & 6.17 \\
\hline 2015 & 5.99 & 16.6 & 1.22 & 2.59 & 0.79 & 0.11 & 3.33 & 5.28 \\
\hline
\end{tabular}

Source: https://data.worldbank.org/data-catalog THE WORLD BANK GDP IN TRILLIONS OF U.S. \$

Figure 1 below, shows the GDP growth rates for both countries for $1971-2015$. Obviously by looking at the graph we can see that the growth rates for both countries have been very volatile, but have only been negative for a couple of years. The conclusion is that they are both going the same direction.

Figure 1



In Figure 2 below we see the inflation rates for both. Both countries have been running very low rates, even negative at times.

FIGURE 2 


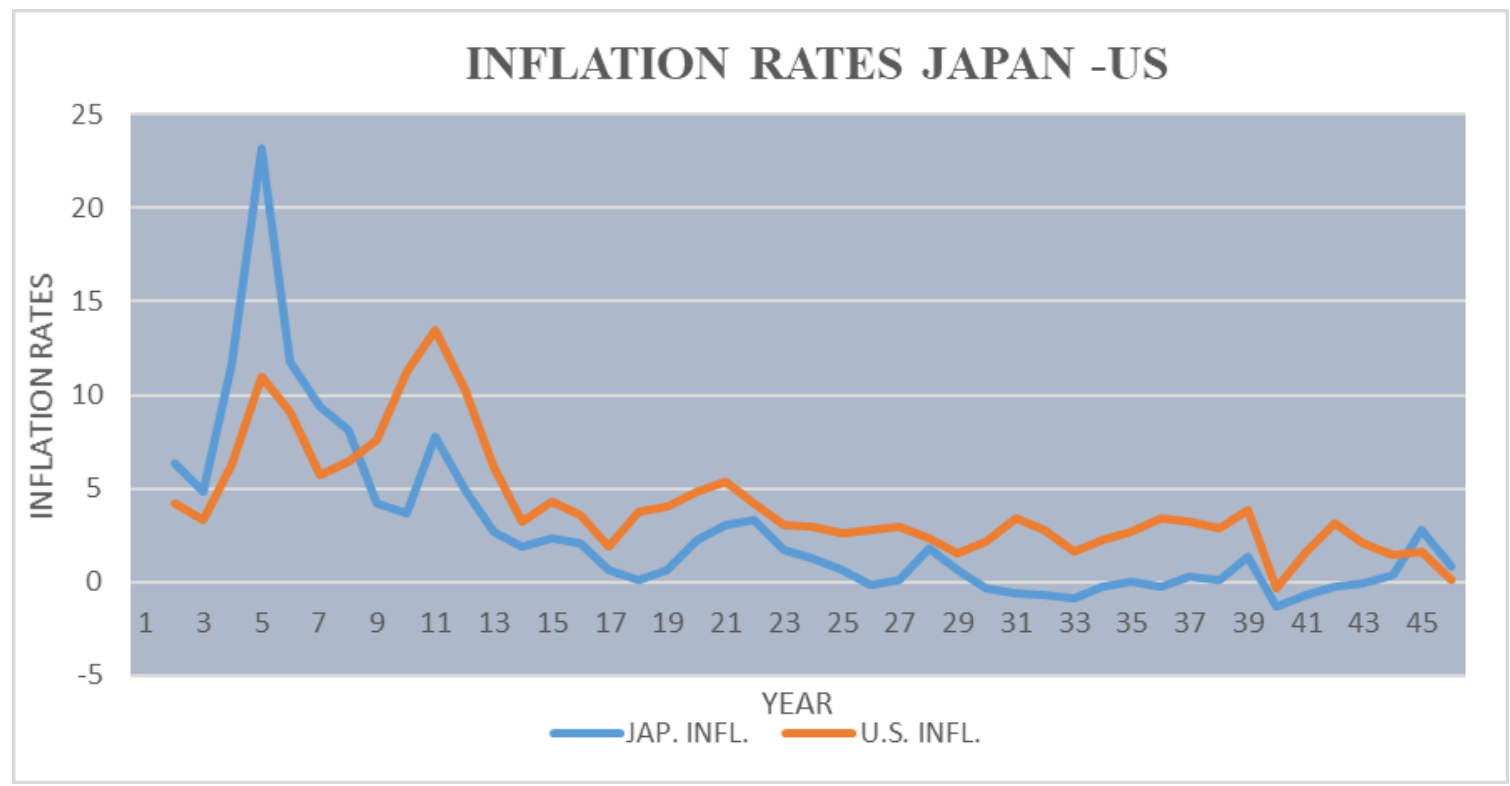

The next figure, Figure 3, shows the unemployment rates for the two countries. On this graph we can see two things. Other than a couple of years, the unemployment rate of Japan has been lower than the U.S., and for the most part more stable than that of the U.S. The second thing we can see here, is that for the last several years, the unemployment rates in both countries have been declining.

FIGURE 3




TABLE 2

U.S. - JAPAN DATA $1971-2015$

\begin{tabular}{|c|c|c|c|c|c|c|c|c|}
\hline YEAR & $\begin{array}{l}\text { US } \\
\text { EXP.X }\end{array}$ & $\begin{array}{l}\text { JAP } \\
\text { EXP X }\end{array}$ & $\begin{array}{l}\text { US } \\
\text { IMP. M }\end{array}$ & $\begin{array}{l}\text { JAP } \\
\text { IMP M }\end{array}$ & $\begin{array}{l}\mathbf{X}-\mathbf{M} \\
\mathbf{U S}\end{array}$ & $\begin{array}{l}X-M \\
\text { JAP }\end{array}$ & POPUL. & POPUL. \\
\hline & $\begin{array}{l}2010 \\
\text { US\$ }\end{array}$ & $\begin{array}{l}2010 \\
\text { US\$ }\end{array}$ & $\begin{array}{l}2010 \\
\text { US\$ }\end{array}$ & $\begin{array}{l}2010 \\
\text { US\$ }\end{array}$ & $\begin{array}{l}2010 \\
\text { US\$ }\end{array}$ & $\begin{array}{l}2010 \\
\text { US\$ }\end{array}$ & US & JAPAN \\
\hline 1971 & 0.198 & 0.095 & 0.288 & 0.16 & -0.09 & -0.065 & 208 & 106 \\
\hline 1972 & 0.214 & 0.091 & 0.314 & 0.176 & -0.1 & -0.085 & 210 & 107 \\
\hline 1973 & 0.254 & 0.104 & 0.329 & 0.219 & -0.075 & -0.115 & 212 & 108 \\
\hline 1974 & 0.274 & 0.128 & 0.322 & 0.229 & -0.048 & -0.101 & 214 & 110 \\
\hline 1975 & 0.273 & 0.127 & 0.286 & 0.205 & -0.013 & -0.078 & 216 & 112 \\
\hline 1976 & 0.284 & 0.148 & 0.342 & 0.219 & -0.058 & -0.071 & 218 & 113 \\
\hline 1977 & 0.291 & 0.166 & 0.379 & 0.228 & -0.088 & -0.062 & 220 & 114 \\
\hline 1978 & 0.322 & 0.165 & 0.412 & 0.243 & -0.09 & -0.078 & 223 & 115 \\
\hline 1979 & 0.354 & 0.172 & 0.419 & 0.275 & -0.065 & -0.103 & 225 & 116 \\
\hline 1980 & 0.392 & 0.202 & 0.391 & 0.254 & 0.001 & -0.052 & 227 & 117 \\
\hline 1981 & 0.397 & 0.229 & 0.401 & 0.259 & -0.004 & -0.03 & 229 & 118 \\
\hline 1982 & 0.367 & 0.232 & 0.396 & 0.257 & -0.029 & -0.025 & 232 & 118 \\
\hline 1983 & 0.357 & 0.243 & 0.446 & 0.248 & -0.089 & -0.005 & 234 & 119 \\
\hline 1984 & 0.386 & 0.281 & 0.555 & 0.275 & -0.169 & 0.006 & 236 & 120 \\
\hline 1985 & 0.399 & 0.295 & 0.591 & 0.267 & -0.192 & 0.028 & 238 & 121 \\
\hline 1986 & 0.43 & 0.28 & 0.641 & 0.277 & -0.211 & 0.003 & 240 & 121 \\
\hline 1987 & 0.477 & 0.28 & 0.679 & 0.302 & -0.202 & -0.022 & 242 & 122 \\
\hline 1988 & 0.554 & 0.299 & 0.706 & 0.359 & -0.152 & -0.06 & 244 & 123 \\
\hline 1989 & 0.618 & 0.327 & 0.737 & 0.423 & -0.119 & -0.096 & 247 & 123 \\
\hline 1990 & 0.672 & 0.35 & 0.763 & 0.457 & -0.091 & -0.107 & 250 & 124 \\
\hline 1991 & 0.717 & 0.369 & 0.762 & 0.452 & -0.045 & -0.083 & 253 & 124 \\
\hline 1992 & 0.767 & 0.385 & 0.816 & 0.447 & -0.049 & -0.062 & 257 & 124 \\
\hline 1993 & 0.792 & 0.386 & 0.886 & 0.442 & -0.094 & -0.056 & 260 & 125 \\
\hline 1994 & 0.862 & 0.401 & 0.992 & 0.478 & -0.13 & -0.077 & 263 & 125 \\
\hline 1995 & 0.95 & 0.418 & 1.07 & 0.54 & -0.12 & -0.122 & 266 & 125 \\
\hline 1996 & 1.03 & 0.438 & 1.16 & 0.299 & -0.13 & 0.139 & 269 & 126 \\
\hline 1997 & 1.15 & 0.487 & 1.32 & 0.601 & -0.17 & -0.114 & 273 & 126 \\
\hline 1998 & 1.18 & 0.475 & 1.48 & 0.561 & -0.3 & -0.086 & 276 & 126 \\
\hline 1999 & 1.21 & 0.484 & 1.63 & 0.581 & -0.42 & -0.097 & 279 & 127 \\
\hline 2000 & 1.31 & 0.546 & 1.84 & 0.635 & -0.53 & -0.089 & 282 & 127 \\
\hline 2001 & 1.24 & 0.509 & 1.78 & 0.641 & -0.54 & -0.132 & 285 & 127 \\
\hline 2002 & 1.21 & 0.549 & 1.85 & 0.646 & -0.64 & -0.097 & 288 & 127 \\
\hline 2003 & 1.24 & 0.601 & 1.93 & 0.668 & -0.69 & -0.067 & 290 & 128 \\
\hline
\end{tabular}




\begin{tabular}{|r|r|r|r|r|r|r|r|r|}
\hline 2004 & 1.36 & 0.687 & 2.15 & 0.722 & -0.79 & -0.035 & 293 & 128 \\
\hline 2005 & 1.44 & 0.736 & 2.29 & 0.766 & -0.85 & -0.03 & 296 & 128 \\
\hline 2006 & 1.57 & 0.812 & 2.43 & 0.802 & -0.86 & 0.01 & 298 & 128 \\
\hline 2007 & 1.72 & 0.882 & 2.5 & 0.82 & -0.78 & 0.062 & 301 & 128 \\
\hline 2008 & 1.82 & 0.896 & 2.43 & 0.825 & -0.61 & 0.071 & 304 & 128 \\
\hline 2009 & 1.46 & 0.686 & 2.1 & 0.696 & -0.64 & -0.01 & 307 & 128 \\
\hline 2010 & 1.5 & 0.857 & 2.36 & 0.774 & -0.86 & 0.083 & 309 & 128 \\
\hline 2011 & 1.52 & 0.855 & 2.49 & 0.819 & -0.97 & 0.036 & 312 & 128 \\
\hline 2012 & 1.55 & 0.854 & 2.55 & 0.863 & -1 & -0.009 & 314 & 128 \\
\hline 2013 & 1.58 & 0.861 & 2.58 & 0.891 & -1 & -0.03 & 316 & 127 \\
\hline 2014 & 1.62 & 0.941 & 2.69 & 0.965 & -1.07 & -0.024 & 319 & 127 \\
\hline 2015 & 1.66 & 0.969 & 2.81 & 0.966 & -1.15 & 0.003 & 321 & 127 \\
\hline
\end{tabular}

Source: https://data.worldbank.org/data-catalog THE WORLD BANK

EXPORTS AND IMPORTS IN TRILLIONS OF US \$

NET EXPORTS $(X-M)$ IN TRILLIONS OF US \$

POPULATION IN MILLIONS

The next figure shows the exports and the imports of both countries, as well as their total trade. One thing that draws our attention here is that the U.S. imports (M) are rising at a very fast pace. On the other hand its net exports $(\mathrm{Xn}=\mathrm{X}-\mathrm{M})$ are positive for most of the years, whereas for the U.S., that is sharply negative.

Figure 4

U.S. - Japan Trade 


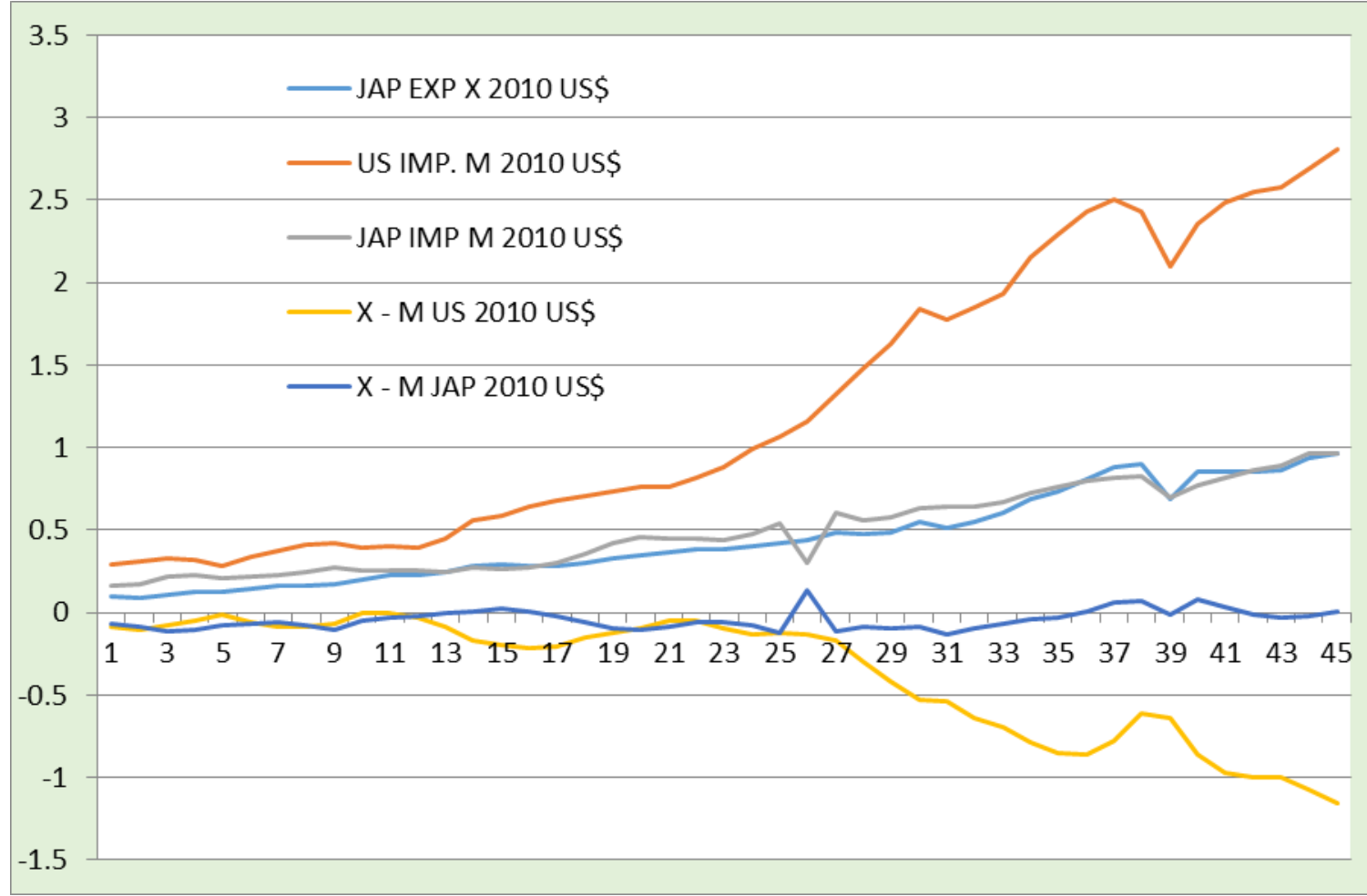

All figures in trillions of US 2010 dollars

Figure 5

U.S. - Japan Population

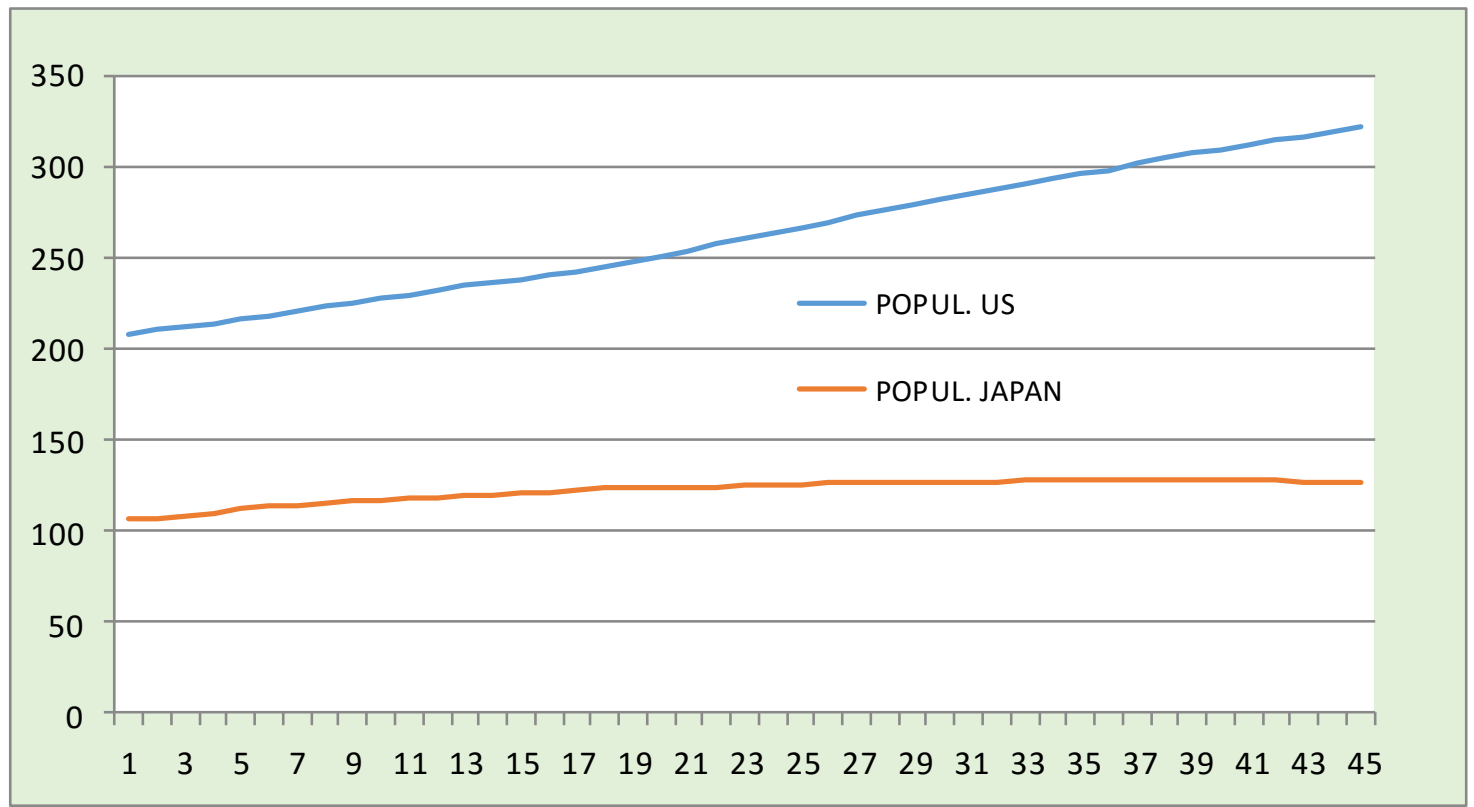

Finally, the last figure above compares the population size of the two countries. For the U.S., although a much bigger population size, it is increasing much faster than that of Japan, even though its population is increasing as well but at much slower pace. 


\section{Conclusion}

This last section is designed to summarize what was presented in the last few pages about the economy of Japan, and how it compares to the United States, and finally make some recommendations about how to turn things around.

It is widely accepted that Japan is the closest competitor to the United States, since it is the second biggest economy in the world. In the two tables and the graphs, we can easily see and derive the conclusion that the Japanese economy is growing and is very competitive, but it is still much smaller than that of the United States. The Japanese unemployment rate, shown on Table 1 as well as the inflation rates also on Table 1 and Figures 2 and 3 show better economic conditions in Japan than the U.S. As far as the net trade (Xn) is concerned, shown on Table 2 and Figure 4, both countries have, for several years between 1971 and 2015, negative trade balance, which means that they both import much more than they export.

Finally, what needs to be done in Japan? The Economic Strategy Council states that a new economic system needs to be developed in Japan, so that people will regain their confidence. As a result the Council makes the following recommendations:

In concluding this section, we can safely say, based on the data presented, that both of these economies had their ups and downs, but for the most part they are comparable to each other.

1. The Japanese must be convinced that they are in an economic recovery, so that they will not be worried about a fiscal crisis. The Japanese must also be shown the steps of structural reforms. If these are done then the economy will be on its way to recovery within two years.

2. The Japanese government needs to encourage a competitive society and to eliminate regulations and over protectionism. Also employment must be reformed, and things like deregulation and improvements in the accounting methods should take place.

3. Reform the financial system. A new financial system must be created, and the various institutions must be revised.

4. The fourth recommendation is about industrial revitalization and international competitiveness. This can be achieved with the help of the government by allowing the businesses to eliminate excess business machinery and invest their resources heavily in promising industries.

5. The last recommendation concentrates on the improvement of the standard of living in the $21^{\text {st }}$ century.

In conclusion, the Economic Strategy Council states that if these recommendations are taken seriously, then it will be only a matter of time before the Japanese economy improves both in the private and the public sectors.

At this point the authors would like to say that the paper is not complete by any means. As stated above, there are several issues that are not conclusive and further research is needed in 
order to be able to derive stronger conclusions. To this end, any recommendations and suggestions will be appreciated.

\section{Bibliography}

“-. "The Case of Daiei”, Understanding Japan, Denver, Co: November, 1994: Vol. 3, Number 7.

--------. “Trade Fences Exact Big Costs". The Japan Times. Tokyo: December 26 - January 1, 1995: Vol. 34, Number 54, page 11.

----------. "Problems in Long - Term Growth". Japan Economic Institute Report. Washington, DC: Japan Economic Institute, April 29, 1994.

Country Briefings - Japan, Economic Structure, http://www.economist.com, April 6, 2004, Retrieved April 25, 2006.

Ellington, Lucien, “Japan's Economy: 21 st century challenges”, May 1995, http://www.indiana.edu/, Retrieved April 25, 2006.

Hall, Whitney J., “Japan from Prehistory to Modern Times”, Delacorte Pess, New York, 1968. Japanese Chronological Table, http://www.rekihaku.ac.jp/e_ctable/index.html, Retrieved March 10, 2006.

Japanese History: A timeline, http://www.askasia.org Retrieved March 10, 2006.

Japanese History: Overview, http://www.japan-guide.com, Retrieved March 10, 2006.

Katz, Richard. Japanese Phoenix: The long Road to Economic Revival. New York: M. E. Sharpe, 2002.

Lincoln, Edward J., “Japans Unequal Trade”, Washington, DC: The Brookings Institution, 1990.

Mark, James, Shyam Sunder, Shigueynki Aloe and Kazuhiro Igawa. Japan: why it works, why it doesn't. Economics in Everyday Life. Honolulu: University of Hawaii Press, 1988.

Strategies for Reviving the Japanese Economy. http://www.kantei.go.jp/foreign/senryaku/intro.html, Retrieved April 25, 2006.

\section{Appendix}

In this section of the paper, the authors ran several regressions using the data presented earlier in the paper. The regressions are an attempt to measure and compare aspects of the economies of the United States and of Japan. The hypothesis for each test is presented along with the findings and a graph illustrating the regression.

\section{$\underline{\text { Model \#1 }}$}

The first model uses US GDP Growth rate as independent and Japan's Inflation rate as dependent. The hypothesis is that Japan's Inflation rate does not depend on the US GDP Growth rate. The value of the $\mathrm{R}^{2}$ is 0.008 , so less than $1 \%$ of Japan's Inflation rate depends on the US GDP Growth rate. The $\mathrm{P}$ value for this hypothesis test is 0.566 . Since this value is larger than 0.05 , the hypothesis is accepted, meaning that US GDP Growth has no impact on Japan's inflation. The results are shown in the figure below. 
Figure 1

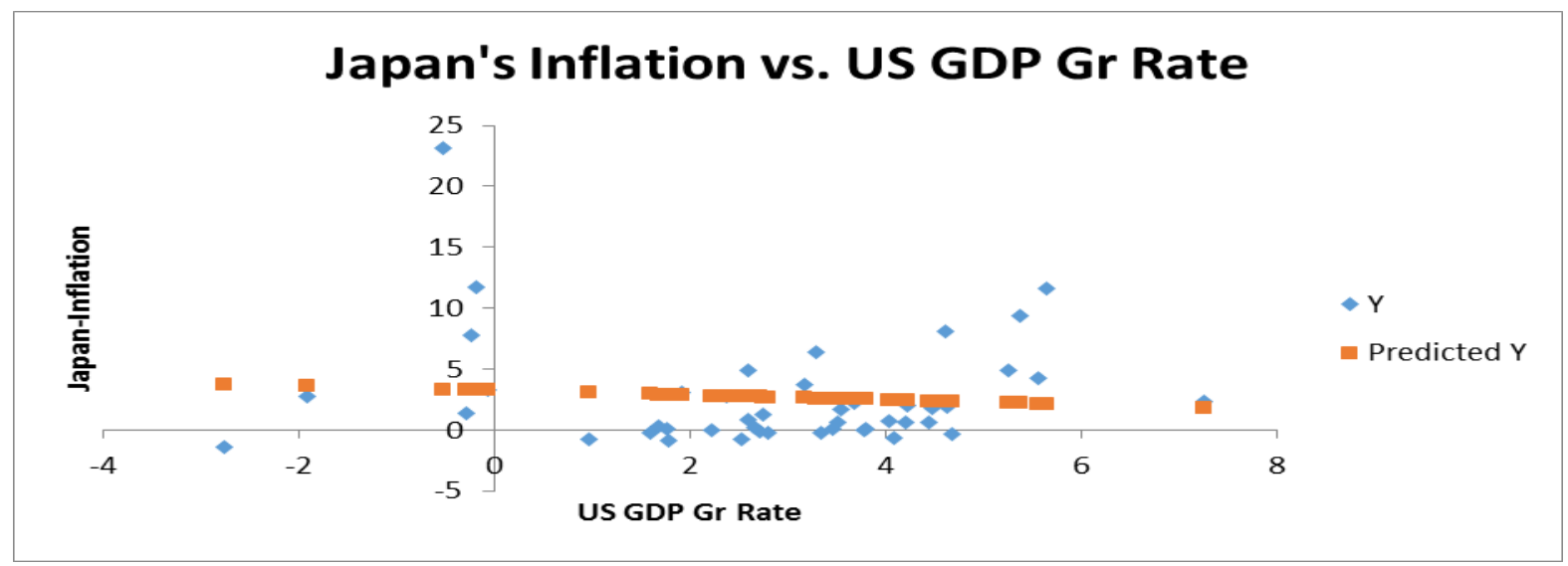

$\underline{\text { Model \#2 }}$

The second model uses Japan's GDP Gr Rate as independent and the US Inflation Rate as dependent. The hypothesis is that US Inflation Rate does not depend on Japan's GDP Gr Rate. The value of the $\mathrm{R}^{2}$ is 0.128 , so roughly $13 \%$ of the US Inflation Rate depends on Japan's GDP Gr Rate. The $\mathrm{P}$ value for this hypothesis test is 0.016 . Since this value is smaller than 0.05 , the hypothesis is rejected, which in fact means that since the P value is so small, Japan's GDP Gr. Rate has a strong impact on US Inflation.

These results are shown below in Figure 2

Figure 2

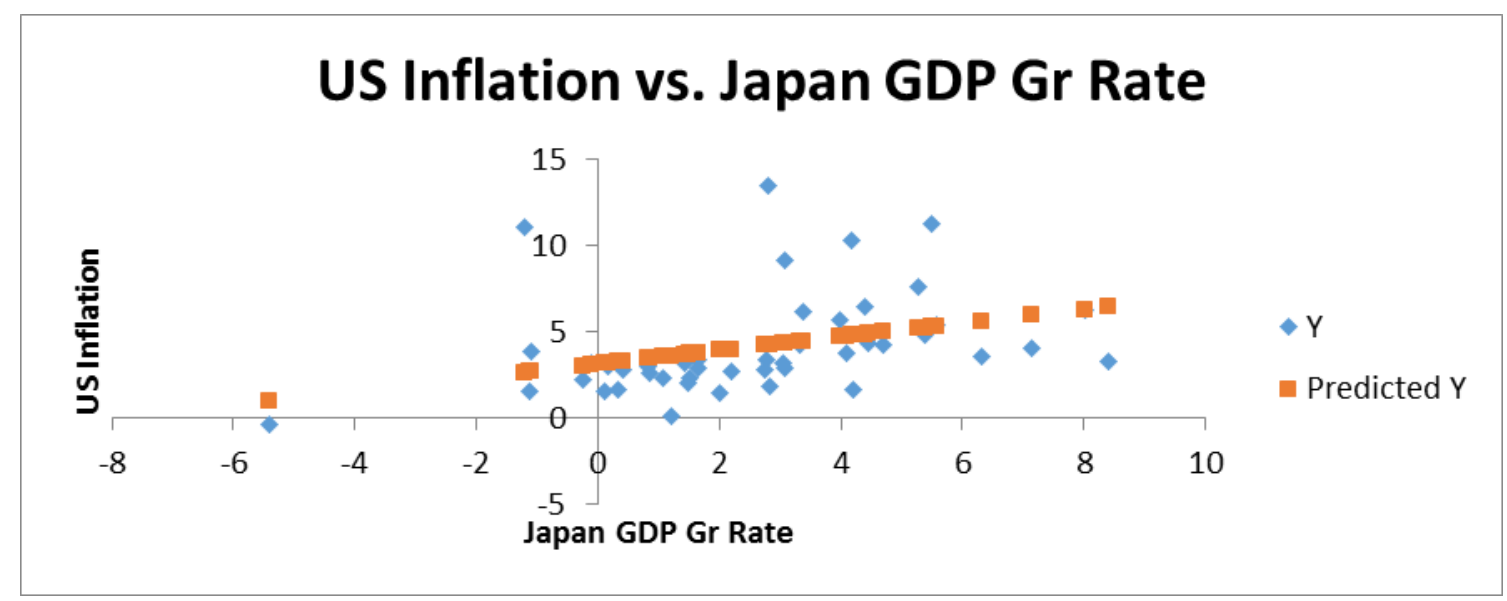

$\underline{\text { Model \#3 }}$ 
The third model uses Japan's net exports as independent and the United States unemployment rate as dependent. The hypothesis is that the United States unemployment rate does not depend on Japan's net exports. The value of the $\mathrm{R}^{2}$ is 0.122 , so roughly $12 \%$ of the United States unemployment rate depends on Japan's net exports. The P value for this hypothesis test is 0.019 . Since this value is smaller than 0.05 , the hypothesis is rejected, which basically means that the more Japan exports the higher the unemployment in the US is. These results are shown in Figure 3 on the next page.

Figure 3

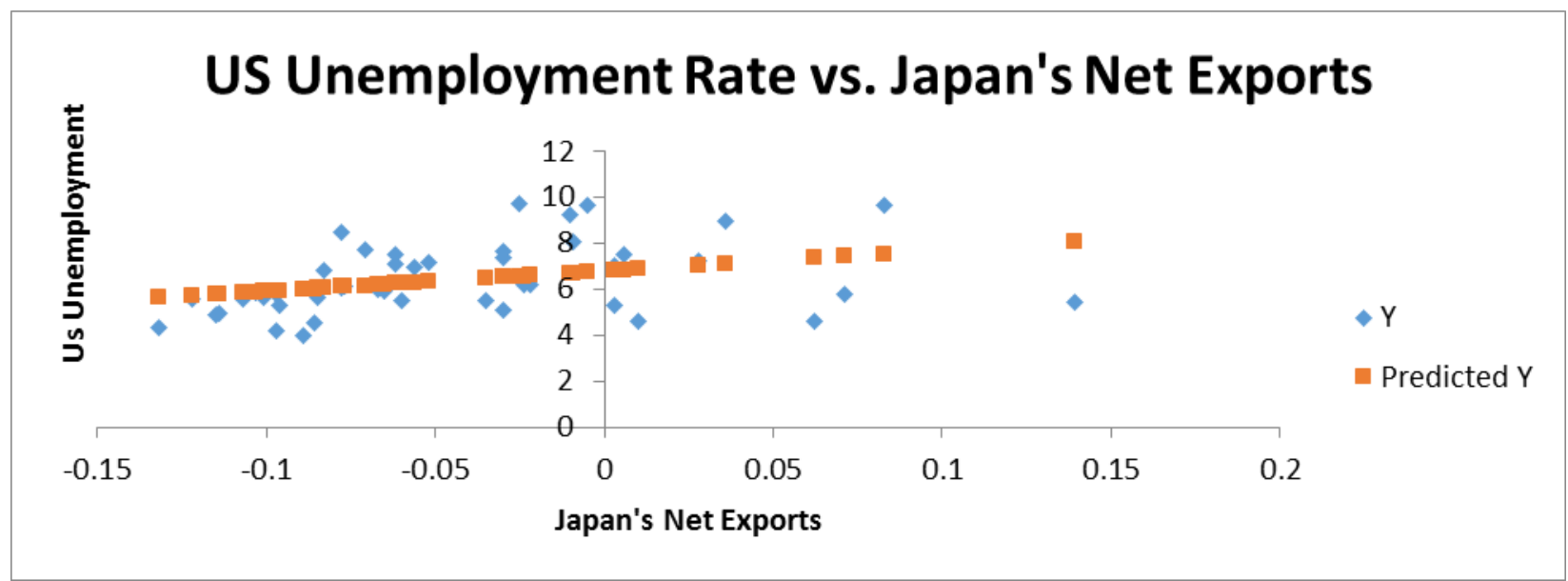

\section{Model \#4}

The fourth model uses the United States' net exports as independent and Japan's Unemployment rate as dependent. The hypothesis is that Japan's Unemployment rate does not depend on the United States' net exports. The value of the $\mathrm{R}^{2}$ is 0.593 , so roughly $60 \%$ of Japan's Unemployment rate depends on the United States' net exports. The P value for this hypothesis test is $6.18 \times 10^{-10}$. Since this value is smaller than 0.05 , the hypothesis is rejected. This shows basically the same thing as model 3, except that US net exports have a much more negative impact on Japan's unemployment. These results are shown below in Figure 4.

Figure 4 


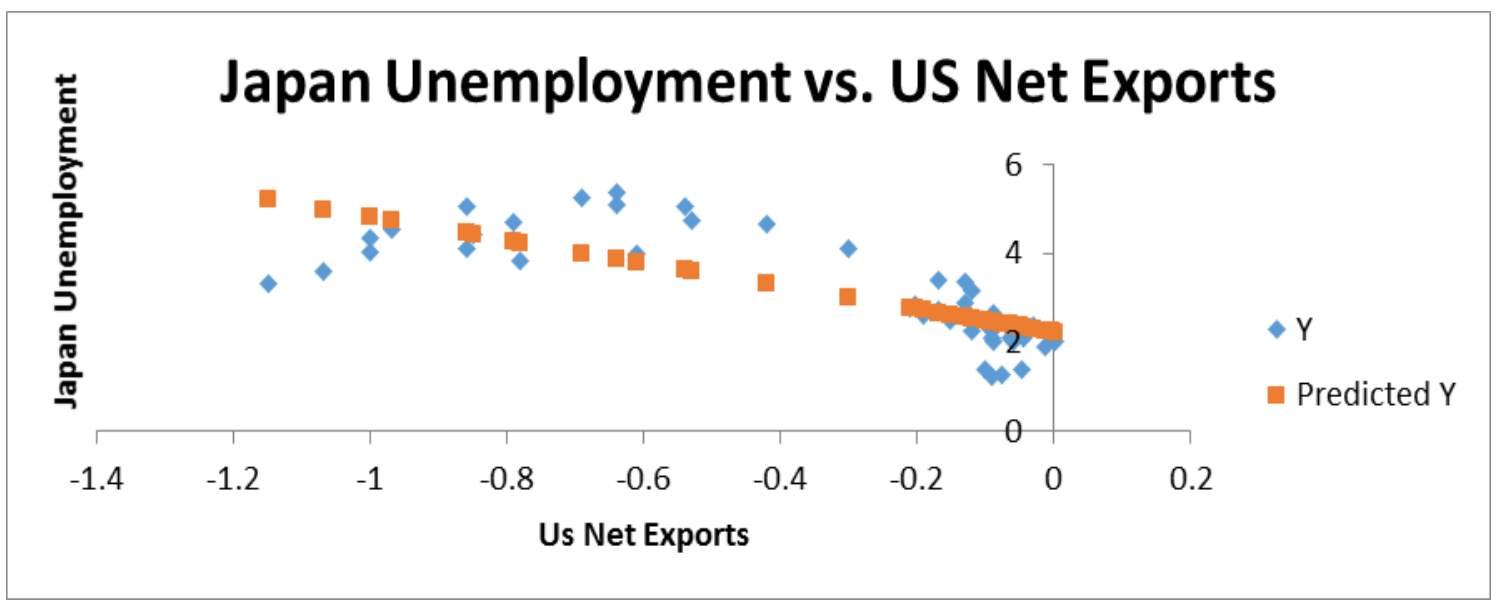

\section{Model \#5}

The fifth model uses Japan's Population as independent and US GDP Growth rate as dependent. The hypothesis is that the US GDP Growth rate does not depend on Japan's Population. The value of the $\mathrm{R}^{2}$ is 0.034 , so roughly $3 \%$ of the US GDP Growth rate depends on Japan's Population. The $\mathrm{P}$ value for this hypothesis test is 0.234 . Since this value is larger than 0.05 , the hypothesis is accepted. These results are shown below in Figure 5.

Figure 5

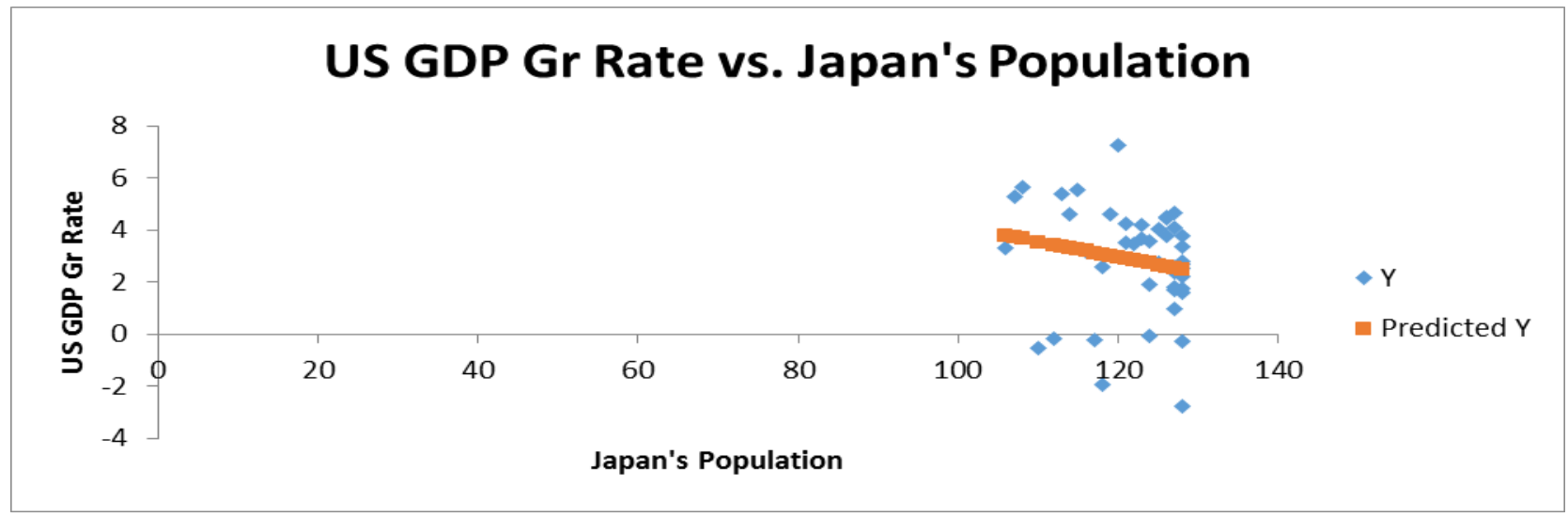

Model \#6

The final model uses the US Population as independent and Japan's GDP Gr Rate as dependent. The hypothesis is that Japan's GDP Gr Rate does not depend on the US Population. The value of the $\mathrm{R}^{2}$ is 0.379 , so approximately $38 \%$ of Japan's GDP Gr Rate depends on the US Population. The $\mathrm{P}$ value for this hypothesis test is $6.67 \times 10^{-6}$. Since this value is smaller than 0.05 , the hypothesis is rejected. This model basically shows that the US, due to its size, has a very strong economic impact on Japan, unlike the other way around in the previous model. These results are shown on the next page in Figure 6.

Figure 6 




\section{Conclusion}

In concluding the appendix, the authors attempted to measure aspects of the economies of the United States and of Japan, as well as the impact they have on each other. We believe this way we can get a picture of how the two countries' economies are related to each other. Obviously, our regression models and results show that the Japanese economy depends on the US much more than the other way around. Even though the results are interesting, they are not 100\% conclusive. More work is needed before we can say that the results are solid. To that end, any suggestions or recommendations that can improve and can take this paper a step further will be appreciated. 